\title{
The Communication Strategy of The Tourism Office of Pangkalpinang City in Promoting The Potency of Lempah Kuning as Gastronomic Tourism in The New Normal Era
}

\author{
Agung Ferianda ${ }^{1}$, Ferdiana $^{2}$ \\ \{agung.ferianda@stisipolp12.ac.id ${ }^{1}$, ferdiana@stisipolp12.ac.id² \\ Communication Department, STISIPOL Pahlawan 12, Sungailiat, Bangka, \\ Indonesia $^{1}$, Communication Department, STISIPOL Pahlawan 12, Sungailiat, \\ Bangka, Indonesia ${ }^{2}$
}

\begin{abstract}
The research objective is that the Financing Company in Pekanbaru is a company engaged in financing that is distributed to the public in the form of credit or loan. This study examines how the influence of organizational characteristics, worker characteristics, environmental characteristics, management policies and practices, and leadership on organizational effectiveness in finance companies. The results of this study indicate that organizational characteristics have contributed to organizational effectiveness. The variables of environmental characteristics, worker characteristics and organizational and leadership characteristics have a significant contribution and effect on organizational effectiveness. Meanwhile, the variables of management policies and practices do not have a contribution to $\mathrm{Y}$ or have no significant effect on organizational effectiveness.
\end{abstract}

Keywords: Marketing Management, Communication Strategy, Gastronomic Tourism

\section{Introduction}

In 2018 the Provincial Government of Bangka Belitung focused on the development of tourism awareness and charm programs. This program empowers and fosters the community so that they can play an important role in tourism development, one of which is welcoming and offering regional specialties or culinary delights to foreign tourists. Especially the city of Pangkalpinang, which is the capital of Bangka Belitung Province, which emphasizes more on the attractiveness of culinary tourism as an effort to attract tourists.

One of the specialties in Bangka Belitung which is also popular in Pangkalpinang City is Lempah Kuning. Lempah Kuning is a famous Bangka culinary delicacy that has been included in the intangible cultural heritage since 2015. Lempah Kuning are made from fresh fish with a sauce that has a sweet and sour taste and is yellow in color. However, fish can also be replaced with beef or chicken, but the more popular Lempah Kuning that made from fish. The people of Bangka add spices such as shallots, garlic, chilies, shrimp paste, turmeric, and galangal. Meanwhile, to add to the sour taste, you can use tamarind, pineapple, kedondong leafes, starfruit and so on. This dish can be served warm to eat with rice or not. The following is an illustration of Lempah Kuning cooking: 


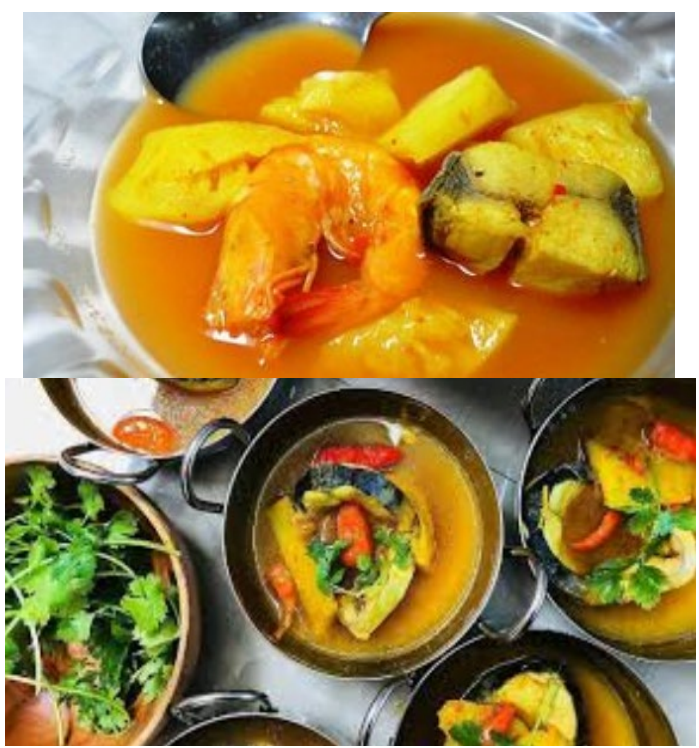

Figure 1. Illustration of Lempah Kuning

Source: google.com

Lempah Kuning is a cultural heritage of cuisine from generation to generation in Bangka Belitung. Not least in Pangkalpinang where there are number of restaurants provide this special culinary. Data on the number of restaurants and food stalls in Pangkalpinang City in 2018 were 119 with $70 \%$ of which were restaurants or food stalls that served Bangka specialties including Lempah Kuning.

Lempah Kuning are not only seen from the point of view of their main function as a fulfillment of physiological needs, namely food, but more than that this culinary can be an attraction for gastronomic tourism. Gastronomy is a guide regarding various ways that involve everything about food and drink. The study is very interdisciplinary which deals with the reflection of a history, cultural impact and environmental atmosphere regarding "How (How), where (where), when (when), and why (why). Gastronomy or culinary is the art or science of good food (Good eating) [1].

In gastronomic studies, Lempah Kuning is an intangible cultural heritage that has cultural values describing the environmental conditions of the Bangka Belitung people, known as the archipelago province. This heritage needs to be conveyed to both domestic and foreign visitors as a tourist attraction. The efforts of delivery merely requires the proper of communication strategy, especially in the new normal era due to the Covid-19 pandemic. Whether we like it or not, living side by side with Covid-19 forces us to live in different lifestyle. Including in the tourism which is currently decreasing globally. Therefore, the Tourism Office of Pangkalpinang City especially at the departement of promotion, must play a role in determining what kind of communication strategies need to done in an effort to promote the potential of Lempah Kuning as a gastronomic tourist attraction in this new normal era.

\section{Literature Review}




\subsection{Marketing Management Concepts}

Marketing management is a human effort to achieve the desired exchange result and build close relationship with consumers in a way that is beneficial to the company. Meanwhile, Stanton (2005) states that marketing management as a mean that is used by businesses to carry out marketing [2].

States that marketing management is the analysis, planning, implementation and control of programs designed to create, form, and maintain beneficial exchanges with target buyers of the organization [3].

\subsection{Communication Strategy}

Essentially Communication strategy is planning and management to achieve goals. In conveying a message, a communicator must create an effective communication in order to have the desired effect on the communicant. To create an effective communication, a communicator should think about how the message can be conveyed properly to audiences starting from the method of presenting the message, the media used in conveying the message, and so on. [4]

In order to deliver the messages to the public effectively, there are several communication strategies needed [5]:

1. Knowing the Audience

Knowing the audience is the first step for communicators in effective communication efforts. In the communication process, the audience is considered to be a party who is not passive at all, but active. So that between communicators and communicants there is not only a relationship, but also influence each other.

2. Compose the Message

After knowing the audience and the situation, the next step of the formulation of a communication strategy is to compose a message, namely determining the theme and material. Messages can be conveyed face-to-face or through a communication medium. The content of a message can be in the form of science, entertainment, information, advice or propaganda. The requirements of an effective message are attractive, can meet the individual needs (personal needs) of the communicant, messages can satisfy emotional needs, messages can satisfy the logical expectations of the recipient of the message.

3. Establish Methods

In addition, to knowing the audience and strengthening the content of the message, the method of delivering a communication is also one of the important things so that effectiveness of communication can be achieved.

4. Selection and Use of Media

The choice of media in communication must be selective, means the communicator should see and adjust the circumstances and conditions of the audience to the communication media to be used. This is because the situations and conditions of the communicants are not all the same, such as communication media which have their own advantages and disadvantages

\subsection{Tourism Concept}

Tourism is a very complex phenomenon of human mobility, products and services. This is very closely related to organization, institutional and individual correlations, the need for services, the provision of service needs and so on. [6] 
Tourism has several impacts as the economic impact as a country's foreign exchange, social impact as a means of being able to open employment opportunities, and cultural impacts, namely a place to show, introduce culture and art of a region. [7]

\subsection{Gastronomy Concepts}

Gastronomy according to Rao, Monin \& Durand Gastronomy describes the influence of the environment (geography and climate) and culture (history and ethnicity) on the components of aroma, texture and taste in food and beverages. Gastronomic identity is of interest of a region (State) in determining cultural diversity and culinary rhetoric. According to Gilleisole gastronomy or culinary is the art, or science of good food (good eating). The shorter explanation mentions gastronomy as anything related to the pleasure of eating and drinking [8]

\section{Methods}

The research carried out a qualitative research method with a descriptive approach. Researchers use the descriptive methods to obtain a description of the research. The descriptive research is a research method that seeks to describe and interpret objects naturally. [9]

\section{Result and Discussion}

Researchers conducted interviews and documentation from some of activities of the Tourism Office of Pangkalpinang City to find out about the communication strategy of the Pangkalpinang City Tourism Office in promoting the potential of Lempah Kuning as a gastronomic tourist attraction in the new normal era. In this study, interviews were conducted with the Pangkalpinang City Tourism Office, Lempah Kuning businessman and tourists.

\subsection{Audience Identification}

The use of communication for marketing or introducing a product in tourism should show audience or the target clearly. Meanwhile, tourist classification was the way of the audience identification in the Tourism Office of the Pangkalpinang City. Following is the explanation of Riharnadi, Head of the Promotion Section of the Pangkalpinang City Tourism Office:

"Identification of audiences through target tourist targets. Tourists are divided into two part both local tourists or in their own area and tourists outside the Bangka area. Then "Mancanegara" tourists are foreign tourists. This determines the message that must be conveyed in several languages and through what media so that the audience is reached in terms of access to information.

Both domestic and foreign tourists are the target audience for a tourism communication strategy. The data of the visit number of domestic and foreign tourist visits to Pangkalpinang city in 2018 based on data obtained from the Tourism Office of Pangkalpinang City are as follows: 


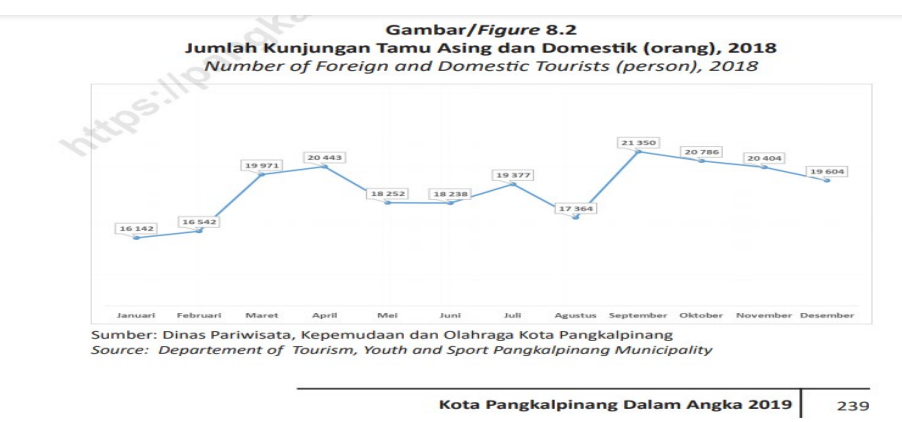

Figure 2. Graphic of the Number of Visits from foreign and domestic guests 2018

Based on the graphic above, we can analyze the movement of the number of tourist visits both domestic and foreign to the city of Pangkalpinang. The lowest level of visits was in January 2018 around 16,142 people, while the highest was in September 2018 around 21,350 people.

Based on data on the number of visits by foreign and domestic guests of Pangkalpinang city in 2018 obtained from the Central Statistics Agency of Bangka Belitung province in 2018. In 2016 the number of visits was 1,009 people, then in 2017 it increased to 1,663 people while in 2018 it increased quite sharply to 3,159 people. Meanwhile, for domestic tourists in 2016, there are only 196,999 people, increased in 2017 with 212,579 people, increased again in 2018 , up to 225,314 people. As for the total, it is clear to note that in 2016 there were 198,008 people then in 2017 , it increased to 214,242 people, last in 2018 it increased to 228,473 people, not too significant.

This indicates an increase in the number of tourist visits both domestic and foreign to Pangkalpinang city from year to year. So obviously the need for food or culinary also increases. Because traveling activities are never separated from eating or culinary activities.

\subsection{Composing a Message}

Whether it is effective or not, a communication depends on the content of the message, including the potenty of communication strategy of Lempah Kuning in new normal era nowadays. The theme of the message should be attractive as well as its content. As Riharnadi, Head of the Promotion Section of the Pangkalpinang City Tourism Office stated:

"One of the city tours in Pangkalpinang is culinary. The website is currently being updated due to changes to three languages Indonesian, Mandarin and English. This is done as a result of an analysis of the percentage of the number of domestic and foreign tourist visits to Pangkalpinang. From the percentage of tourist visits are tourists from China, China or countries that use Mandarin, then English such as from the Netherlands, Malaysia and so on, who speak English. The theme is the message of Lempah Kuning cultural value, what ingredients are made of and accompanied by cooking methods, pictures to videos".

The use of three languages on the website has basic reasons. This is coming from an analysis of tourist visits so far. Beside the domestic tourist visits who Indonesian native speaker, the use of Mandarin and English was chosen because of the analysis of the following country visit data:

Table 1. International tourists to Pangkalpinang in 2018

Number Country of origin Total Language




\begin{tabular}{llll}
\hline 1 & RRC/China & 54 people & Mandarin \\
2 & Malaysia & 4 people & Mandarin/Melayu \\
3 & Netherlands & 2 people & English \\
4 & Thailand & 210 people & Mandarin/Thai \\
5 & Australia & 4 people & English \\
6 & USA & 5 people & English \\
7 & India & 10 people & English /India \\
8 & South Korea & 2 people & Mandarin/Korea \\
\hline
\end{tabular}

Whether a message is interesting or not will affect the effectiveness of a communication. In composing the message, it must use language that is easily understood by the audience. Messages are not only in the form of writing, but also in the form of images and sounds. Messages on social media such as Facebook, Twitter, and websites are more in writing and pictures platforms. Although there are some who use audio visuals, the dominance of writing and visuals is more pronounced in this social media. One of them is about the communication of Lempah Kuning, not only from related agencies, but ordinary people can also promote it. Like the author's search results below:

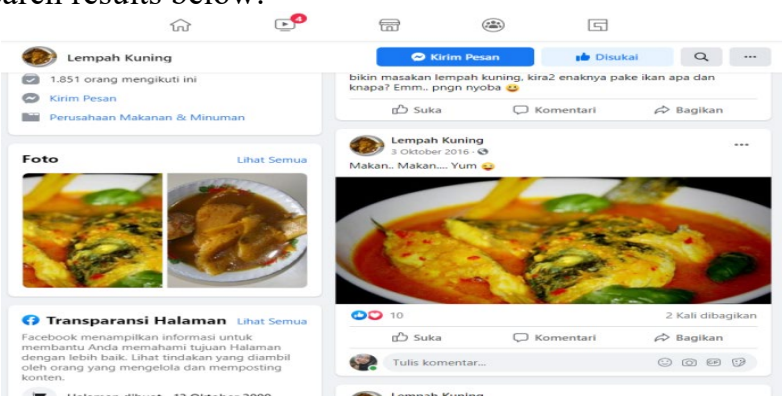

Figure 3. Social media post about Lempah Kuning

Based on the picture above, it can be seen that a Facebook account of Lempah Kuning always posts things about this special dish. The message was conveyed trough writing platform that has an informative tone to invite netizens to taste, this can be seen from the post

"eat...eat...yummy"

Apart from that, from the picture point of view, this account shows an appetizing Lempah Kuning because of its bright yellow color and the blend of spices that are clearly visible in the picture. There are a lot of followers of the account with 1,851 people. This is an indication that people who have seen and followed the account so that they can always monitor the development up to thousands of people.

\subsection{Methods}

The method of delivery in a communication strategy is also a very important thing, it will determine how to approach these audiences. Based on the exploration at the Tourism Office, it was found that the method of delivery was focused more on information and education about the cultural values of Lempah Kuning, the taste of Lempah Kuning, and the persuasion method by inviting tourists to come to Pangkapinang Bangka Belitung. To strengthen this, it can be seen in the following image: 


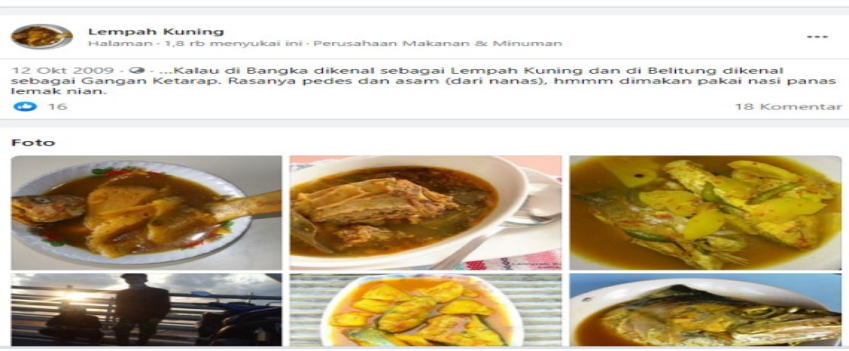

Figure 4. Lempah Kuning social media post

The post above provides information about the different designations or names of Lempah Kuning between Bangka and Belitung.

"In Bangka it is known as Lempah Kuning and in Belitung it is known as Gangan Ketarap. It tastes spicy and sour (from pineapple) hmmm, eat it with hot rice (it's delicious) "

The sentence above contains informative, educative and persuasive tone. It is a method that used in a marketing communication strategy. By this method, people especially tourists certainly will be interested and curious to try.

\subsection{Selection and Selection of Media}

In today's new normal era, we must prioritize health protocols. Any communication strategy must be adjusted to the conditions. Media selection is an important thing in the communication strategy of the potency of Lempah Kuning as a tourism attraction. Following is the explanation of Riharnadi, Head of the Promotion Section of Tourism Office:

"Social media was chosen to adjust to the new normal conditions in order to maintain health protocols. In addition to the effectiveness of this, it was carried out for the efficiency of budget recofussing due to Covid-19 so that conventional media was temporarily not used. Not only using social media belonging to the Pangkalpinang City Tourism Office, but also through stakeholder collaboration such as business actors in the culinary, tourism and general public sectors. The choice of social media is also because it follows the development of the digital age. In an effort to disseminate cultural values and local wisdom in Lempah Kuning not only limited to local communities but throughout the archipelago and even the world. This requires media that is able to reach it, one of which is social media that can be accessed throughout the world"

Social media is indeed the most widely used in the tourism sector to promote its tourism potential. Especially at this time with the new normal condition, online media, especially social media, are considered the most realistic to be used for targeted promotions. Considering that internet users in Indonesia are quite high, this is evidenced by the 2019 Indonesian Internet Service Providers Association (APJII) survey quoted from kompas.com that out of a total population of 264 million Indonesians, there are 171.17 million or around 64,8 percent are already connected to the internet. [10]

The following are some of the captures obtained by researchers from the official Facebook social media account belonging to the Pangkalpinang City Tourism Office regarding Lempah Kuning: 

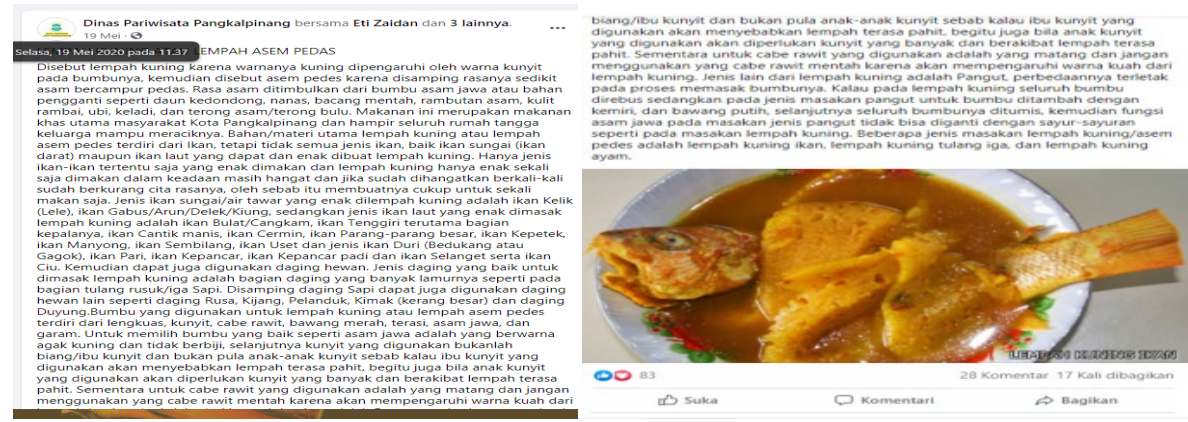

Fig 5. Social media posts of the Pangkalpinang City Tourism Office

Based on the capture from Facebook post, there is a narrative that provides information about the Lempah Kuning cuisine, ingredients and flavors. In addition, it is also equipped with a picture of the Lempah Kuning itself. Public feedback can be seen immediately from the number of likes with 83, 28 comments and this post was shared up to 17 times. This indicates that social media is the simplest and most effective means of disseminating information about a tourist attraction, including gastronomic tourism of Lempah Kuning.

Not only through social media owned by the Tourism Office, the post of Lempah Kuning was also carried out by the online version of the printed mass media, Bangka Pos, which also participated in promoting one of Lempah Kuning restaurant owned by a local businessman. In a Bangka Pos YouTube account, entitled "The Enjoyment of Lempah Kuning and Land Spices at Popular Prices at Hersya Restaurant". There is a testimony of Lempah Kuning sold at the restaurant. This is an indication that the current promotion efforts have shifted to online media which are more easily accessible to both domestic and foreign tourists.

\section{Conclusion}

Based on the results, the research concluded that the communication strategy used by the Tourism Office of Pangkalpinang City has been carried out an initial analysis so it increase the effectiveness and the efficiency of promotion financing in the middle of the new normal era. Social media was selected in order to maximize the promotion of Lempah Kuning that targeting domestic and foreign tourists by using informative, educative and persuasive delivery methods.

\section{Reference}

[1] B. Santich, "The study of gastronomy and its relevance to hospitality education and training," Int. J. Hosp. Manag., vol. 23, no. 1, pp. 15-24, 2004, doi: 10.1016/S0278-4319(03)00069-0.

[2] Priansa, Perilaku Konsumen dalam Bisnis Kontemporer. Bandung: Alfabeta, 2017.

[3] D. Sunyoto, Konsep Dasar Riset Pemasaran dan Perilaku Konsumen. Yogyakarta: CAPS (Center for Academic Publishing. Service, 2014.

[4] O. Effendy, Humas Membangun Citra Dengan Komunikasi. Bandung: PT.Remaja Rosdakarya, 2005.

[5] A. Arifin, Strategi Komunikasi :Sebuah Pengantar Ringkas. Bandung: armico, 2008. 
[6] D. Weber, Perencanaan Ekowisata dari Teori ke Aplikasi. Yogyakarta: PUSPAR UGM dan Andi, 2006.

[7] A. Muljadi, Kepariwisataan dan Perjalanan. Jakarta: PT RajaGrafindo Persada, 2009.

[8] A. R. Krisnadi, "Gastronomi Makanan Betawi Sebagai Salah Satu Identitas Budaya Daerah," Natl. Conf. Creat. Ind., no. September, pp. 5-6, 2018, doi: 10.30813/ncci.v0i0.1221.

[9] H. Darmadi, Metode Penelitian Pendidikan. Bandung: Alfabeta, 2011.

[10] Kompas.com, “APJII: Jumlah Pengguna Internet di Indonesia Tembus 171 Juta Jiwa Artikel ini telah tayang di Kompas.com dengan judul 'APJII: Jumlah Pengguna Internet di Indonesia Tembus 171 Juta Jiwa', Klik untuk baca: https:/tekno.kompas.com/read/2019/05/16/03260037/a.". 